\title{
IDENTIFYING CORRUPTION RISKS IN THE DEFENSE AND SECURITY SECTOR: EMPIRICAL EVIDENCE USING THE GOVERNMENT DEFENSE ANTI-CORRUPTION INDEX
}

\section{Oliver Cover and SAAd Mustafa}

Oliver Cover was Project Lead, Indices at Transparency International U.K.'s Defense and Security Program, London, U.K. He may be reached at oli.cover@gmail.com. Saad Mustafa is Research Lead at Transparency International U.K.'s Defense and Security Program, London, U.K. He may be reached at saad.mustafa@transparency.org.uk.

\section{Abstract}

This article contributes to the debate on conceptualizing corruption by suggesting that sector-specific typologies of corruption risks are useful heuristics that encourage understanding of corruption without attempting to define it in a way that is inherently contestable or inappropriately succinct. To develop this position, this article reflects on the difficulties in trying to define corruption in both general terms and within the context of the defense and security sector. It then details a corruption risk typology in use in the sector, explains how it was used to provide the theoretical backdrop for a global index, and then submits the typology's five main risk areas to empirical testing using that same index's results. The models that result show that this typology's risk areas display sufficient internal coherence for its key risk areas to be of use not only to practitioners, but also to the sector analyst and academic attentive to conceptual concerns.

$\mathrm{C}$ orruption remains a contested term. In the defense and security sector, better conceptualization of the term is possible when preferring a heuristic, sector-specific, and coherent typology over a catch-all definition. In this article a Transparency International typology of corruption risks in the defense and security sector is analyzed. Finding the internal coherence of the typology sound, it is suggested that the approach to measuring corruption can be exported to other sectors of interest.

Previous studies on corruption have tended to divide the issue into four schools of thought: moralist, legalist, market-centered, and public interest. All four exhibit flaws and biases. Moralists, dating back to Machiavelli, Montesquieu, and Rousseau, take the most censorious view, seeing all forms of corruption as wicked and contributory to unstitching society's social fabric. Not only is corruption considered the process by which the virtue of a citizen is destroyed, it is seen as the tool by which a properly functioning political system transcends into an evil one. Yet moralist definitions have been criticized for many years for their inclination to assume that Western standards of morality are universally applicable. As has been evidenced by the international engagement in Afghanistan in recent years, certain behaviors that Westerners may consider corrupt - for instance, nepotism and small bribes to facilitate access to decisionmakers - may not be considered corrupt by locals. ${ }^{1}$

The legalist view attempts to overcome inconsistencies in the moralist definition by combining formal duties of public office with the existing laws of the country in order to judge whether certain behavior is, or is not, corrupt. In essence, corruption occurs where a public official breaks the law for private gain. Yet when officials have not broken any law, or when no law exists to regulate potentially questionable conduct, corruption is not indicated and this may be counterintuitive. In the defense sector, for instance, many countries lack laws on off-budget spending and how this should regulated. If such off-budget spending is diverted for the purposes of influencing decisions behind closed doors, a consistent legalist would be forced to accept this as noncorrupt activity. A legalist definition of corruption tends to focus on political means to profit from private ends which are criminal or otherwise illegal. While such a definition excludes ambiguous moral standards, it nonetheless suffers from clear weaknesses. It overemphasizes the role of the individual at the expense of cadres and entrepreneurs that may similarly engage in corrupt behavior for collective rather than personal gain. Moreover, the law may itself be political, shaped by those who have the opportunity to be corrupt. ${ }^{2}$

Market-centered definitions discard moral and legal concerns and reduce corruption to interaction between the bureaucrat and the public, where a corrupt bureaucrat seeks to maximize income. This makes measurement of corruption problematic since the services governments provide may be difficult to price. Military motivations are, in principle, driven by professional concerns and not by economic incentives. If the primary aim of the armed forces is safeguarding a country's 
borders and not engagement in the national economy, the conceptualization of the sector as a market for rent-seeking is incomplete. Exceptions may, however, exist in countries such as Pakistan, Bangladesh, and Indonesia, where the military has a substantial stake in the economic interests of the country through military-owned businesses. ${ }^{3}$

The public interest school defines corruption through a prism in which a corrupt act undermines systems of civil or public order and, thereby, adversely affects the public interest. But public interest may have different connotations depending on the circumstances. A facilitation payment to a defense official might be considered a corrupt act. Yet what if that payment ensures movement of troops to a specific geographic area requiring protection, and this promotes the safety of citizens? If citizen protection is in the public interest, it is necessary to conclude that this payment is noncorrupt. ${ }^{4}$

Perhaps the simplest and most widely used definition of corruption is offered by Transparency International: Corruption is "the abuse of entrusted power for private gain." Even this can be regarded as incomplete: What normative standards define "abuse"? As an alternative, definitions emphasizing corruption as public officials violating impartiality to attain illicit ends may hold resonance. Yet elected officials are almost always - and presumably should be — partial to their mandate. Therefore the concept of impartiality is problematic as well: Competitive politics requires partiality, and subdividing the concept into a narrower form of impartiality - of process, for example, or in opportunity offered to companies bidding for a contract, or candidates applying for a job-begs the question of precisely what the definition should include. ${ }^{5}$

More recently, corruption has been framed as a principal-agent problem: Agents engage in corrupt activity, freed from a potentially honest principal due to the costs associated with on-going control of agents. Whether one can truly identify an honest principal in a deeply corrupt system is uncertain, of course, and agents may have little incentive to refrain from corrupt practices if they feel that their superiors will not follow suit. Corruption might instead be seen as a social trap, its eradication requiring collective action. Corruption would be combated by changing the agent's calculus such that he or she believes that nonparticipation in corrupt activities will lead to similar, noncorrupt, practice by other actors. Yet economic sectors, and actors within the sectors, differ, which begs further questions. For example, incentives applicable to a high-ranking bureaucrat who oversees defense expenditure may differ from those applicable to low-ranking troops seeking rents from citizens; incentives to prevent company officers offering bribes may differ from those appropriate to prevent government officials receiving them. ${ }^{6}$
The article discusses moralist, legalist, market-centered, public-interest, and other considerations of corruption. It then presents and applies Transparency International's view and measurement of corruption to the defense and security sector. Using factor analysis, it finds that TI's index of corruption in this sector is sound, and suggests that the approach may be exported to other public sectors potentially affected by corruption.

\section{Corruption in the defense and security sector}

Rather than constructing a distinct definition for corruption in the defense and security sector (DSS), some authors highlight various ways in which the sector varies from civilian public offices. Military discipline relies on a properly functioning hierarchy and chain of command which instills order among the ranks. Corruption, however, promotes the antithesis of such discipline. The behavior of high-ranking officials has a disproportionately significant effect on the standards to which soldiers adhere.

The Defense and Security Program of the U.K. branch of Transparency International (TI-DSP) has developed a typology of corruption risks in the defense and security sector. It identifies five key corruption risks-political, financial, personnel, operations, and procurement - that act as pillars by which sub-risks may be grouped. The typology was developed after consultation with senior defense practitioners and government officials from across countries who have worked on anti-corruption. The typology has gone through several iterations, the most recent of which was in 2011. It is expected to continue to evolve, as new corruption risks - cyber-security, for example_-come to prominence.

The typology is a guideline. Although the five key risk areas are likely to be in some way reflected in each country's corruption-risk profile, not all of the sub-risks will apply to each country in equal measure. Thus the typology is flexible, and the sub-risks' relevance may be considered individually when applied to a specific country.

The five key risk areas are: ${ }^{7}$

- Political: The risk of defense legislation and controls being compromised by corruption (23 variables).

- Financial: The risk of abuse of large, potentially secretive budgets and income (11 variables).

- Personnel: The risk of corruption among armed forces and defense ministry personnel (18 variables).

- Operations: The risk of corruption occurring during military operations at home or abroad (5 variables).

- Procurement: The risk of corruption in the process of purchasing defense equipment and arms (20 variables). 
The typology, and the sub-risks, are presented in Table 1. (Full explanations of the sub-risk areas are publicly available. ${ }^{8}$ ) The typology does not offer a definition, or outline a catch-all concept, of corruption. Rather, as a heuristic — a device that guides learning - the typology reflects those areas in which corruption risk may occur. For example, in political risk, the sub-risk defense budgets reflects the potential for oversight of the budget to be compromised, and for these funds to be redirected illicitly or unlawfully. In financial risk, the sub-risk military-owned businesses reflects the possibility of illicit personal enrichment to occur as a result of the operations of profit-making enterprises owned by the military establishment. In procurement risk, the offsets sub-risk reflects the risk of unlawful or secretive payments made as part of countertrade contracts. At no time is lawfulness, public interest, or standards of public office, invoked as a necessary consideration. Thus the typology circumvents definitional or conceptual considerations. Instead, it offers a practical framework by which one may understand corruption.

Feedback from TI-DSP training sessions for middle and senior-ranked defense officials that use the typology as a basis for understanding corruption in the sector has been positive, suggesting that it fits the reality of corruption incidence on the ground, is comprehendible, and cross-culturally applicable. Yet to an analyst of corruption or of the defense and security sector, or both, interested in a research framework, how might the five key risk areas, and the sub-risks associated with them, be put to use? A recently released index of levels of defense and security corruption risk provides an indication of the potential for such a typology to be used in a major study.

\section{Using the typology}

Transparency International's Government Defense Anti-Corruption Index 2013 (GI) was launched in January 2013 and generated considerable media and government attention. Two reports, one detailing the key findings worldwide and the other specific to the Middle East and North Africa (MENA) region, were published simultaneously. The theoretical backdrop to the GI rests on three attributes. First, the index, of course, is driven by the defense corruption risk
Table 1: Corruption risk areas and sub-risks in the defense and security sector

\begin{tabular}{|c|c|c|c|c|}
\hline Political & Financial & Personnel & Operations & Procuremen \\
\hline $\begin{array}{l}\text { Defense and } \\
\text { security } \\
\text { policy }\end{array}$ & $\begin{array}{l}\text { Asset } \\
\text { disposals }\end{array}$ & $\begin{array}{l}\text { Leadership } \\
\text { behavior }\end{array}$ & $\begin{array}{l}\text { Disregard of } \\
\text { corruption in } \\
\text { country }\end{array}$ & $\begin{array}{l}\text { Technical } \\
\text { req's and } \\
\text { spec's }\end{array}$ \\
\hline $\begin{array}{l}\text { Defense } \\
\text { budgets }\end{array}$ & $\begin{array}{l}\text { Secret } \\
\text { budgets }\end{array}$ & $\begin{array}{l}\text { Payroll, HR, } \\
\text { rewards }\end{array}$ & $\begin{array}{l}\text { Country } \\
\text { within } \\
\text { mission }\end{array}$ & $\begin{array}{l}\text { Single } \\
\text { sourcing }\end{array}$ \\
\hline $\begin{array}{l}\text { Nexus of } \\
\text { defense } \\
\text { national } \\
\text { assets }\end{array}$ & $\begin{array}{l}\text { Military- } \\
\text { owned } \\
\text { businesses }\end{array}$ & Conscription & Contracting & $\begin{array}{l}\text { Agents and } \\
\text { brokers }\end{array}$ \\
\hline $\begin{array}{l}\text { Organized } \\
\text { crime }\end{array}$ & $\begin{array}{l}\text { Illegal } \\
\text { private } \\
\text { enterprise }\end{array}$ & Salary chain & $\begin{array}{l}\text { Private } \\
\text { security } \\
\text { companies }\end{array}$ & $\begin{array}{l}\text { Collusive } \\
\text { bidders }\end{array}$ \\
\hline $\begin{array}{l}\text { Control of } \\
\text { intelligence } \\
\text { services }\end{array}$ & & $\begin{array}{l}\text { Values and } \\
\text { standards }\end{array}$ & & $\begin{array}{l}\text { Financing } \\
\text { package }\end{array}$ \\
\hline \multirow{4}{*}{$\begin{array}{l}\text { Export } \\
\text { controls }\end{array}$} & & Small bribes & & Offsets \\
\hline & & & & $\begin{array}{l}\text { Contract, } \\
\text { award, } \\
\text { delivery }\end{array}$ \\
\hline & & & & $\begin{array}{l}\text { Sub- } \\
\text { contractors }\end{array}$ \\
\hline & & & & $\begin{array}{l}\text { Seller } \\
\text { influence }\end{array}$ \\
\hline
\end{tabular}

typology. The five key risk areas and the sub-risks associated with them directed the focus of a detailed questionnaire. The questions were answered by an assessor with defense and anti-corruption expertise, and two independent reviewers then challenged or confirmed each assessor's scoring and qualitative justifications. TI national chapters and, where they responded, government points of contact, were also given the opportunity to comment. ${ }^{9}$

Second, the concept of corruption risk was integral to question development. Questions were designed to identify policies, institutions, and behaviors that might affect particular corruption risks, both in terms of their potential frequency and their potential severity. Dividing the concept of risk into these twin concepts is important: Procurement questions tend to focus on the severity issue, the capacity of oversight processes to prevent potentially highly costly arms scandals. Questions on personnel tend to relate to lower-level corruption that might occur in greater frequency, facilitation payments, for example, or nepotistic recruitment.

Third, the GI is a hybrid index. A hybrid index may be limited to whether it is input or output-based, that is, whether 
it seeks to identify rules in place or the effectiveness of those rules. But in the case of GI, both aspects are captured: For the top scores to be awarded by an assessor in the GI, both de jure and de facto circumstances must indicate clear likelihood that corruption risk is curtailed. The GI is also hybrid in that it spans the dichotomy between numerical and descriptive indicators: All quantitative scores are backed by narrative justification. The GI is hybrid a third way: Where possible, it combines rigorous assessor-based analysis with government commentary. ${ }^{10}$

The GI results were stark in their indication of the high levels of corruption risk in the defense and security sector worldwide. Countries were banded according to overall score, and 69 percent of them were placed in Bands D, E, and F, which indicated the award of less than half of the total marks available, and high, very high, and critical risk of corruption in the sector, respectively. Table 3 outlines the banding schema and the countries attached to each band.

Results by key area of the risk typology are indicative of specific concerns. In terms of political risk, there are minimal formal mechanisms for scrutiny of defense policy in 45 percent of countries covered. Secrecy is considerable in finance risk, affecting asset disposals, military-owned businesses, and the defense budget. In terms of personnel risk, scores are generally higher across countries, with many militaries possessing robust payment structures and formal measures to tackle corrupt troops. In operations, few countries possess military doctrine, operational training, or monitoring that looks at anti-corruption. Finally, in procurement risk, transparency is limited across countries, and controls of some of the more complex areas of the process such as subcontractors, offsets contracts, and the use of agents, are often weak.

\section{Analyzing the risk areas with factor analysis}

The availability of the index dataset enables more detailed analysis of the defense corruption risk typology and moves the focus from headline results to conceptual considerations. Does rigorous testing of GI data confirm or challenge the five key risk areas identified by the TI-DSP typology? Factor analysis, a statistical tool enabling a broad set of variables to be analyzed, cross-correlated, and implicit factors within these variables to be teased out, can help answer this question.

One way to approach the analysis is to include all 77 variables into a single factor analysis model and see if five factors corresponding to the risk areas emerge. Alternatively, one can take the five risk areas as given and load the variables into five separate models - one each for the political, financial, personnel, operations, and procurement corruption risk areas. If the TI-DSP typology is analytically sound, we should expect
Table 2: GI results by band, 2013

\begin{tabular}{|c|c|c|}
\hline Band & $\begin{array}{l}\text { Overall } \\
\text { scores }\end{array}$ & Countries \\
\hline $\begin{array}{l}\text { A: Very low } \\
\text { risk }\end{array}$ & $\begin{array}{l}83.3 \leq \\
100\end{array}$ & Australia, Germany \\
\hline B: Low risk & $\begin{array}{l}66.7 \leq \\
83.2\end{array}$ & $\begin{array}{l}\text { Austria, Norway, South Korea, } \\
\text { Sweden, Taiwan, United } \\
\text { Kingdom, United States }\end{array}$ \\
\hline $\begin{array}{l}\mathrm{C} \text { : Moderate } \\
\text { risk }\end{array}$ & $\begin{array}{l}50.0 \leq \\
66.6\end{array}$ & $\begin{array}{l}\text { Argentina, Brazil, Bulgaria, } \\
\text { Chile, Colombia, Croatia, Czech } \\
\text { Republic, France, Greece, } \\
\text { Hungary, Italy, Japan, Latvia, } \\
\text { Poland, Slovakia, Spain }\end{array}$ \\
\hline D: High risk & $\begin{array}{l}33.3 \leq \\
49.9\end{array}$ & $\begin{array}{l}\text { Bangladesh, Belarus, Bosnia and } \\
\text { Herzegovina, China, Cyprus, } \\
\text { Ethiopia, Georgia, Ghana, India, } \\
\text { Israel, Jordan, Kazakhstan, } \\
\text { Kenya, Kuwait, Lebanon, } \\
\text { Malaysia, Mexico, Nepal, } \\
\text { Pakistan, Palestine, Russia, } \\
\text { Rwanda, Serbia, Singapore, } \\
\text { South Africa, Tanzania, } \\
\text { Thailand, Turkey, UAE, Ukraine }\end{array}$ \\
\hline $\begin{array}{l}\text { E: Very } \\
\text { high risk }\end{array}$ & $\begin{array}{l}16.7 \leq \\
33.2\end{array}$ & $\begin{array}{l}\text { Afghanistan, Bahrain, Cote } \\
\text { d'Ivoire, Indonesia, Iran, Iraq, } \\
\text { Morocco, Nigeria, Oman, the } \\
\text { Philippines, Qatar, Saudi Arabia, } \\
\text { Sri Lanka, Tunisia, Uganda, } \\
\text { Uzbekistan, Venezuela, } \\
\text { Zimbabwe }\end{array}$ \\
\hline $\begin{array}{l}\text { F: Critical } \\
\text { risk }\end{array}$ & $\begin{array}{l}0 \leq \\
16.6\end{array}$ & $\begin{array}{l}\text { Algeria, Angola, Cameroon, DR } \\
\text { Congo, Egypt, Eritrea, Libya, } \\
\text { Syria, Yemen }\end{array}$ \\
\hline
\end{tabular}

to find a single key factor drawn out from each set. For each set, the factors with eigenvalues over 1.0 were maintained.

Of course, an objection to this approach is that because the questionnaire is structured around the typology, any test of internal coherence is likely to be tautological. But this is not likely to be the case. The reason for this is that during the index methodology design, questions were made highly specific, and detailed model answers provided. The need for assessors to provide specific evidence to back each score reduces any assessor's bias to "cluster" answers by risk area or of introducing a thematic bias that would correspond to GI's risk areas. The factor analysis runs look to confirm that within each risk area, the questions do cluster coherently around that risk area.

The various panels in Table 3 shows the results for each set, summarizing the factors retained, their eigenvalues, and the variables relevant to each. Thus, Panel A, containing the 
political risk variables, three factors exhibit eigenvalues over 1.0, the standard cutoff score. Factor 1 draws out many of the political risk variables, and explains much of the variance in the data. Factors 2 and 3 are rather weaker, with eigenvalues not far over 1.0, and with only limited contribution to the overall variance explained. Factor 2 seems to isolate public trust in the defense establishment to avoid corruption, which correlates well with the existence of institutions to prevent corruption risk and low levels of organized crime linked to the military. Public trust is likely to be affected by both things quite starkly. Factor 3 is driven almost solely by organized crime policing, perhaps reflecting a distinction between law enforcement and defense corruption risk. In sum, the political risk variables are largely coherent, with two additional factors contributing in only a limited way to increased variance explained.

Panel B shows the results for the financial risk variables. With the exception of a single variable, all others cluster onto a single factor. The exception, percentage of secret spending, was, indeed, the variable that countries across the world scored worst in and was one of the most demanding to measure and assess. It required that governments were open about levels of secret spending to the public, not just to the legislature. Openness would help reveal either anomalous fluctuations in levels of such spending or simply high levels of spending, both of which might indicate a potential for secrecy to be used as a corruption smokescreen. In practice, reluctance to make publicly available any detail on secret items is clear, and the variable thus forms a coherent factor in itself.

Panel C turns to personnel-related risk items. A strong first factor with a high eigenvalue appears to be a catch-all across personnel themes, embracing leadership commitment to anticorruption efforts, robust whistle-blowing mechanisms, and addressing code of conduct breaches. Factors 2 and 3 are also retained, but explain only little additional variance. Factor 2 is driven strongly by variables tapping low-value but potentially frequent forms of corruption such as conscription-related bribery, ghost soldiers (nonexistent soldiers on the payroll), and facilitation payments. Factor 3 taps transparency in personnel issues and robust systems of personnel payment.

With regard to operations risk, Panel D shows a single factor, which thus captures every underlying variable. Finally, in terms of procurement-related risk items, Panel E, a more complex picture emerges. Four factors are retained (but only the first two seem worthy of discussion). Factors other than Factor 1 capture only a limited amount of additional overall variance, suggesting considerable coherence among the bulk of the variables within the risk area. Factor 1 displays positive factor loadings across the variables, and is driven by
Table 3: Results of factor analyses

$$
\begin{aligned}
& \text { Factor Eigen- Variables with high loadings } \\
& \text { value }
\end{aligned}
$$
commitment to anti-corruption, whistle-blowing mechanisms, and address code of conduct breaches

$\begin{array}{lll}2 & 1.71 & \begin{array}{l}\text { Low-value/high-frequency corruption } \\ \text { items }\end{array} \\ 3 & 1.27 & \begin{array}{l}\text { Transparency in personnel issues; } \\ \text { robust payment systems }\end{array}\end{array}$

Panel D: Operations risk (5 variables)

$12.89 \quad$ Every operations risk variable, which covers anti-corruption in military doctrine, training, monitoring, contracting, and controls on private military contractors

Panel E: Procurement risk (20 variables)

$\begin{array}{lll}1 & 9.81 & \text { Basic procurement controls } \\ 2 & 1.40 & \text { Technical procurement controls }\end{array}$

fundamental transparency requirements and anti-corruption mechanisms in arms purchases, e.g., disclosure of purchases made, anti-corruption provisions in procurement legislation, open competition and anti-collusion provisions, and quantification of planned purchases. Factor 2 isolates more technical controls, including items pertaining to offset contracts and procurement agents. Factors 3 and 4 cluster variables that are not intuitively reconciled (their eigenvalues are, respectively, 1.22 and 1.04). However, they capture only a very small proportion of the variance. 
The findings for all five risk areas may be summarized as follows:

- General political controls and oversight: Strong

- Public trust and items affecting it: Weak

- Organized crime policing: Weak

- General financial controls and oversight: Strong

- Public disclosure of secret spending: Weak

- General personnel controls and oversight: Strong

- Controls on low-value personnel corruption: Weak

- Transparency in personnel: Weak

- General operations controls and oversight: Strong

- Basic procurement controls and oversight: Strong

- Technical procurement controls: Weak

The five risk areas of the typology appear justified. Factor analysis identifies, in each case, a strong first factor that taps general controls in each of the five areas. Other factors contribute to capture part of the overall variance, but do not challenge the primary factor. Only in procurement-related risk is more of a two-factor division noticeable, between basic and more technical controls, but even here the second factor is not particularly strong.

We ran additional factor analyses in which we separated the 77 variables not into five corruption areas but into two groups, reflecting transparency and oversight. In both cases, however, more than one clear factor was retained, suggesting multiple concepts at play within transparency and within oversight. Thus, it appears that it is preferable to use TI's existing five risks typology as a means of conceptualizing corruption in the sector.

\section{Discussion}

Conceptualizing corruption is problematic but, clearly, of much importance in the defense and security sector, where power can be exercised in palpable forms, secrecy is rife, and budgets are hugely significant to national economies. The TI-DSP defense and security typology helps practitioners break down and assess corruption risk in the sector. A heuristic device useful in training and reform efforts, it has analytical potential as well and forms the backbone of a global index. This article finds that the typology captures conceptually coherent sets of variables, within each risk area. In only a few cases do index items deviate from a coherent main factor in each of the five risk areas analyzed. For us, this analysis suggests two things. First, sector-specific typologies, when developed by experts and subject to judicious revision, can usefully conceptualize corruption without being weighted down by arguments about definitions. Analysts can mount definitional, i.e., interpretative, lenses onto the typology later on. There is reason, then, to support the development of equivalent typologies in other fields relevant to defense and security, and indeed in nondefense and security industries and sectors as well. This need not require statistical analysis from the outset, even if it proves useful later. Theorists interested in conceptualizing corruption in a given sector might start out by considering specific risks and how they group together, keeping definitional concerns on the periphery of their thinking.

Second, TI's existing typology's five main risk areas are, with the caveats provided and using GI data, capable of being made into coherent scales through which further analysis can be undertaken. The data is publicly available, and further analysis is encouraged. The causal properties and determinants of scales relating to the five risk areas are of analytical use. For example, perhaps political corruption risk is explained by constitutional and institutional factors. Procurement corruption risk might be a consequence of openness to trade, the nature of weapons exported, or recency of arms scandals. Such analysis would speak not only to the literature on the determinants of corruption, but also explore how the reduction of the causal factors behind corruption in the defense and security sector may promote peace. Corruption in this sector may be detrimental to peace if the incentive to profit from corrupt arms deals leads to the purchase of unnecessary weapons and prompts reactive purchasing by other countries. The potential for arms races to develop as a consequence of corrupt motivation is yet to be tested but linking such analysis to the causal properties of the underlying corruption would be a salient topic for further work. Thus the typology and its risk areas provide not only a heuristic tool, but also-when used with reference to data provided by the GI-a potentially rich reference point for future research.

\section{Notes}

1. Flaws and biases: Mulvenon (2004). Social fabric: Farrales (2005). Evil one: Friedrich (1989). Universally applicable: Bayley (1966).

2. Otherwise illegal: Bryce (1921). Opportunity to be corrupt: Johnston (1982).

3. Seeks to maximize income: Klaveren (1989).

4. Affects the public interest: Rogow and Lasswell (1977).

5. Define "abuse": Rothstein (2011).

6. Principal-agent: Teorell (2007); Groenendijk (1997). Social trap: Rothstein (2011).

7. See TI-UK (2013a).

8. See TI-UK (2011).

9. Media and government attention: TI-UK (2013c). Published simultaneously: TI-UK (2013a; 2013b). 
10. Hybrid index: UNDP and Global Integrity (2008). Dichotomy: Doig, et al. (2006).

\section{References}

Bayley, D. 1966. "The Effects of Corruption in a Developing Nation.” Western Political Quarterly. Vol. 19, No. 4, pp. 719-732. http://dx.doi.org/10.2307/445147

Bryce, J. 1921. Modern Democracies. Vol.II. New York: St. Martin's Press.

Doig, A., S. McIvor, and R. Theobold. 2006. "Numbers, Nuances, and Moving Targets: Converging the Use of Corruption Indicators or Descriptors in Assessing State Development." International Review of Administrative Sciences. Vol. 72, No. 2, pp. 239-252. http://dx.doi.org/10.1177/0020852306064612

Farrales, M.J. 2005. "What is Corruption? A History of Corruption Studies and the Great Definitions Debate." Working Paper. University of California, San Diego: Social Science Research Network. http://papers.ssrn.com/sol3/ papers.cfm?abstract id=1739962 [accessed 3 May 2013].

Friedrich, C. 1989. "Corruption Concepts in Historical Perspective," pp. 15-24 in A. Heidenheimer, M. Johnston, and T. Levine, eds. Political Corruption: A Handbook. New Brunswick: Transaction Publishers.

Groenendijk, N. 1997. "A Principal-Agent Model of Corruption." Crime, Law and Social Change. Vol. 27, No. 3-4, pp. 207-229. http://dx.doi.org/10.1023/A:1008267601329

Johnston, M. 1982. Political Corruption and Public Policy in America. Monterey, CA: Brooks/Cole Publishing Company.

Klaveren, J. van. 1970. "The Concept of Corruption," pp. 38-40 in A. Heidenheimer, M. Johnston, and T. Levine, eds. Political Corruption: A Handbook. New Brunswick: Transaction Publishers.

Mulvenon, J. 2004. "Dreams of Red Mansions: Causes and Consequences of Chinese Military Corruption." Center for Institutional Reform and the Informal Sector Discussion Paper 0206. College Park, MD: University of Maryland.

Rogow, A. and H. Lasswell. 1977. Power, Corruption, and Rectitude. Westport, CT: Greenwood Press.

Rothstein, B. 2011 "Anti-Corruption: The Indirect 'Big Bang' Approach." Review of International Political Economy. Vol. 18, No. 2, pp. 228-250. http://dx.doi.org/10.1080/09692291003607834

Teorell, J. 2007. "Corruption as an Institution: Rethinking the Nature and Origins of the Grabbing Hand." QoG Working Paper Series 2007:5. The Quality of Government Institute. Gothenburg: University of Gothenburg.

[TI-UK] Transparency International UK. 2011. "Building Integrity and Countering Corruption in Defence and Security: 20 Practical Reforms." Report. London: Transparency International UK.

[TI-UK] Transparency International UK. 2013a. "GI: Government Defence Anti-Corruption Index 2013."
Report. London: Transparency International UK.

[TI-UK] Transparency International UK. 2013b. "Middle East and North Africa Report, GI: Government Defence Anti-Corruption Index 2013." Report. London: Transparency International UK.

[TI-UK] Transparency International UK, 2013c. "Performance Reports: Initial Impact of Defence Companies and Government Anti-Corruption Indices.” Report. London: Transparency International UK.

[UNDP] United Nations Development Programme and Global Integrity. 2008. "A User's Guide to Measuring Corruption." Report. Oslo: UNDP and Global Integrity. 